\title{
Faktor- Faktor Yang Mempengaruhi Kompetensi Penyuluh Pertanian Di Kabupaten Pasaman
}

\author{
${ }^{1}$ Santi Yusneli, ${ }^{2}$ Hery Bachrizal Tanjung \\ ${ }^{12}$ Program Studi Ilmu Penyuluhan dan Komunikasi Pembangunan Universitas Andalas \\ email :santiyusneli17@gmail.com
}

\begin{abstract}
Abstrak
Kabupaten Pasaman terdiri dari 12 kecamatan dengan jumlah penyuluh sebanyak 56 orang yang terbagi atas 48 orang penyuluh pertanian PNS dan 8 orang penyuluh THL-TBPP. Kelompok tani yang ada pada saat ini sejumlah 1.118 kelompok tani. Untuk itu penting mengetahui kompetensi penyuluh pertanian di Kabupaten Pasaman. Tujuan penelitian adalah : 1) menganalisis kompetensi penyuluh pertanian di Kabupaten Pasaman 2) menganalisis faktor-faktor yang mempengaruhi kompetensi penyuluh pertanian. Kompetensi penyuluh pertanian dalam memberdayakan petani, terdiri dari tujuh dimensi yaitu : kompetensi pemahaman potensi wilayah, kompetensi komunikasi inovasi, kompetensi pengelolaan pembelajaran, kompetensi pengelolaan pembaharuan, kompetensi pengelolaan pelatihan, kompetensi pengembangan kewirausahaan dan kompetensi pemandu sistem jaringan. Pelaksanaan penelitian dilakukan dengan pendekatan kuantitatif. Pengambilan data dilakukan dengan menyebarkan kusioner. Penyuluh pertanian yang berjumlah 56 orang secara keseluruhan menjadi sampel dalam penelitian ini. Teknik Analisis data mengunakan regresi linear berganda pada software IBM SPSS Statistik 22. Secara deskriptif hasil penelitian ini menyatakan tingkat kompetensi penyuluh pertanian di Kabupaten Pasaman kategori sedang. Sedangkan secara analisis statistik faktor yang berpengaruh nyata terhadap kompetensi adalah; motivasi, lingkungan dan pengembangan diri sedangkan karakteristik kurang memberi pengaruh nyata terhadap kompetensi penyuluh.
\end{abstract}

Kata Kunci : Kompetensi,karakteristik, motivasi, lingkungan dan pengembangan diri

\begin{abstract}
Pasaman Regency consists of 12 sub-districts with a total of 56 extension workers, divided into 48 civil servant agricultural extension workers and 8 THL-TBPP extension personnel. Currently, there are 1,118 farmer groups. For this reason, it is important to know the competence of agricultural extension agents in Pasaman Regency.The research objectives were: 1) to analyze the competence of agricultural instructors in Pasaman Regency 2) to analyze the factors that influenced the competence of agricultural instructors. The competence of agricultural extension agents in empowering farmers consists of seven dimensions, namely: competency in understanding regional potential, innovation communication competence, learning management competence, renewal management competence, training management competence, entrepreneurial development competency and network system guiding competence. The research was carried out with a quantitative approach. Data was collected by distributing questionnaires. As a whole, 56 agricultural instructors were sampled in this study. The data analysis technique used multiple linear regression on the IBM SPSS Statistics 22 software.Descriptively the results of this study state the level of competence of agricultural extension agents in Pasaman Regency is in the medium category. Meanwhile, in statistical analysis, the factors that significantly influence competence are; motivation, environment and self-development, while the characteristics did not have a real effect on the competence of the instructor.
\end{abstract}

Keywords: Competence,characteristics, motivation, environment and self-development 


\section{PENDAHULUAN}

Penyuluhan merupakan upaya membangun masyarakat secara konvergen, dialogis dan partisipatif sehingga masyarakat bergeser dari yang apatis dan tergantung kepada pihak lain menjadi masyarakat subsistem kemudian berkembang menjadi mandiri merupakan usaha dari pelaksanaan penyuluhan (Sumardjo, 2009).Kompetensi adalah kemampuan yang didasari oleh pengetahuan, keterampilan, sikap dalam menyelesaikan pekerjaan.Kemampuan dan keterampilan yang dimiliki seseorang dalam melakukan pekerjaan untuk mencapai tujuan disebut dengan kompetensi(Boyatzis,1984). Penyuluh pertanian dalam melaksanakan tugas dan fungsi sebagai desiminasi informasi harus memiliki kompetensi dalam penyebarluasan informasi inovasi dari sumber informasi sehingga petani memberikan pernyatan diterima atau tidak informasi inovasi yang disampaikan (Mardikanto, 2009).

Penyuluh merupakan bagian penting dalam pembangunan pertanian. Kabupaten Pasaman memiliki potensi yang besar pada sektor pertanian memiliki peluang dan potensial untuk dikembangkan hal ini dilihat dari luas lahan pertanian 67.852,99 hektar dari luas total lahan. Luas lahan sawah sebesar 26.322,42 hektar kemudian di susul oleh perkebunan rakyat sebesar 26.120,17 hektar kemudian ladang 8.296,02 hektar kebun campuran 6.901,18 hektar dan perkebunan besar sejumlah 212 hektar (BPS.2018).

Pengembangan sektor pertanian dibutuhkan sumberdaya manusia yang memiliki pengetahuan dan keterampilan. Perubahan pengetahuan, sikap dan keterampilan merupakan tujuan penyuluhan, pelaksanaan penyuluhan lebih banyak terhadap pencapaian program-program pemerintah yang bertolak ukur pada peningkatan produksi komoditi startegis. sehingga penyuluh disibukan dengan penyelesaian target produksi yang menjadi tolak ukur dari keberhasilan sebuah program. Mardikanto(2009) menyebutkan bahwa penyuluh dilapangan lebih banyak melaksanakan program pemerintah.

Pelaksanaan kegiatan penyuluhan di Kabupaten Pasaman tahun 2019 dilaksanakan oleh 56 orang penyuluh pertanian yang berada di 12 Balai Penyuluhan Kecamatan. Kelompok tani binaan berjumlah 1.118 kelompok tani, masing - masing penyuluh membina lebih lebih kurang 19 kelompok tani, dengan demikian beban kerja penyuluh akan bertambah. Jumlah kelompok tani binaan yang ideal menurut Departemen pertanian kelompok tani binaan penyuluh yang berada pada wilayah kerja nya antara 6-8 kelompok tani (Hernanda, 2015). Pelaksanaan penyuluhan di Kabupaten Pasaman belum dapat dilakukan secara optimal, hal itu dapat dilihat luas wilayah kerja penyuluh yang tidak sebanding dengan jumlah penyuluh mengakibatkan pembinaan kelompok tani kurang efektif. Menurut Pramono (2017) luasnya wilayah binaan penyuluh akan menjadi kendala bagi penyuluh dilapangan dalam memberikan informasi dan teknologi yang dibutuhkan oleh petani.Tujuan penelitian (1) Menganalisis kompetensi penyuluh pertanian di Kabupaten Pasaman, (2) Menganalisis faktor-faktor yang mempengaruhi kompetensi penyuluh pertanian di Kabupaten Pasaman.

\section{METODE}

Penelitian dilakukan dengan pendekatan penelitian kuantitatif. Penelitian terdiri dari angkaangka dan analisismenggunakan statistik untuk mendapatkan data kejadian masa lampau atau sekarang yang berhubungan dengan keyakinan pendapat perilaku hubungan variabel dan untuk menguji beberapa hipotesis tentang variabel sosiologi dan psikologi dari sampel yang diambil dari populasi tertentu teknik pengumpulan data dengan pengamatan (wawancara atau kusioner) dan hasil penelitian cendrung untuk di generalisasikan disebut juga dengan penelitian kuantitatif (Sugiyono, 2013).

Pada penelitian ini populasi adalah penyuluh pertanian di Kabupaten Pasaman berjumlah 56 orang terdiri dari penyuluh PNS sebanyak 48 orang dan Penyuluh THL-TB PP sebanyak 8 orang yang yang tersebar di 12 kecamatan di Kabupaten Pasaman. Sampel yang digunakan adalah penyuluh PNS dan 
THL-TBPP di Kabupaten Pasaman yang tersebar di 12 Balai Penyuluh Kecamatan. Menurut Efendi(2014)informasi diambil dari seluruh populasi sampel penelitian disebut dengan metode sensusdengan tujuan untuk memperoleh informasi secara lengkap sehingga gambaran kondisi secara keseluruhan.

Penelitian ini yang mengunakan empat variabel indenpenden dan satu variabel dependen dengan definisi operasional sebagai berikut:

a. Karakteristik penyuluh pertanian (X1) adalah sifat yang melekat pada diri seseorang yang mencirikan individu tersebut diukur dengan indikator:

\begin{tabular}{|c|c|c|c|}
\hline No & Indikator & Parameter & Pengukuran \\
\hline 1. & Umur & $\begin{array}{l}\text { Usia umur responden yang diukur mulai } \\
\text { lahir sampai saat penelitian dalam satuan } \\
\text { tahun. }\end{array}$ & $\begin{array}{l}\text { Muda } 26-36 \\
\text { Desawa } 36-45 \\
\text { Tua }>46\end{array}$ \\
\hline 2. & Lama bekerja & $\begin{array}{l}\text { Rentang waktu yang dilalui dalam bekerja } \\
\text { oleh responden sejak mulai sampai } \\
\text { dilakukan penelitian yang diukur dalam } \\
\text { satuan tahun }\end{array}$ & $\begin{array}{l}\text { Rendah }(1-10) \\
\text { Sedang }(11- \\
23) \\
\text { Tinggi }(24-33)\end{array}$ \\
\hline 2. & $\begin{array}{l}\text { Tingkat } \\
\text { formal }\end{array}$ & $\begin{array}{l}\text { tingkat pendidikan tertinggi di terima oleh } \\
\text { responden dibangku sekolah formal, } \\
\text { dihitung dari pendidikan terendah sampai } \\
\text { pendidikan tertinggi diselesaikan, dihitung } \\
\text { dalam satuan tahun }\end{array}$ & $\begin{array}{l}\text { SMA (12 th) } \\
\text { D3(15 th }) \\
\text { S1(16 th })\end{array}$ \\
\hline
\end{tabular}

Sumber : Parmono (2017) Ali Hanafiah. M. (2013)*

Faktor motivasi (X2) yaitu merupakaan dorongan yang dimiliki oleh reponden dalam melaksanakan tugas sebagi penyuluh, dengan indikator yang diukur sebagai berikut

No Indikator Parameter

1. Motivasi berperstasi Tingkat keinginan berkompetisi

Tingkat keinginan maju

Tingkat keinginaan untuk mengikuti pendidikan yang

lebih tinggi

Tingkat keinginan kaji terap sesuai spesipik lokal

Tingkat keinginan untuk bekerja dengan sebaik-

baiknya

Tingkat ketidak tergantungan terhadap imbalan

2. Motivasiberafiliasi

Tingkat keinginan untuk berpartisifasi untuk petani

Tingkat keinginan mendapat respon dari petani

Tingkat keinginan membangun jejaring kerjasama

Tingkat keinginan untuk diterima orang lain

Tingkat keinginan untuk dihargai petani

Tingkat keinginan menjadi tempat konsultasi mencari

solusi. 


\section{Motivasi akan pekerjaan}

Dorongan memilih untuk berada pada jabatan fungsional penyuluh

Sumber: Parmono, (2017)

b. Faktor lingkungan (X3) yaitu faktor yang berada diluar diri responden adapun indikator dan pengukuran sebagai berikut:

\begin{tabular}{|c|c|c|}
\hline No & Indikator & Parameter \\
\hline 1. & Struktur o & $\begin{array}{l}\text { 1. Efektifitas pelaksanaan tugas dan peran penyuluh } \\
\text { 2. Efektifitas komunikasi penyuluh dengan atasan } \\
\text { 3. Struktur sederhana pembagian tugas dan wewenang } \\
\text { 4. Komunikasi dan peran oleh atasan kepada anggota } \\
\text { berlangsung secara menyenangkan }\end{array}$ \\
\hline & Sarana prasarana & $\begin{array}{l}\text { 1. Ketersediaan sarana dan prasaran penyuluh berupa bahan } \\
\text { publikasi, trasportasi dan komunikasi. } \\
\text { 2. Keterjangkuaan sarana saat diperlukan. } \\
\text { 3. Dukung pendanaan kegiatan penyuluhan dalam } \\
\text { peningkatan kompetensi melalui pelatihan dalam daerah } \\
\text { dan luar daerah oleh pemerintah. } \\
\text { 4. Ketersedian sarana komunikasi }\end{array}$ \\
\hline & Dukungan teknologi & $\begin{array}{l}\text { 1. Ketersediaan teknologi spisifik seperti uji tanah } \\
\text { 2. Penyuluh mengetahui penggunaan teknologi } \\
\text { 3. Kemudahan akses informasi } \\
\text { 4. Dukungan ujicoba inovasi }\end{array}$ \\
\hline & Beban kerja & $\begin{array}{l}\text { 1. Tugas administrasi yang dikerjakan } \\
\text { 2. Melaksanakan penyuluhan } \\
\text { 3. Jumlah kelompok binaan } \\
\text { 4. Jumlah desa binaan } \\
\text { 5. Program peningkatan produksi pertanian }\end{array}$ \\
\hline
\end{tabular}

Sumber : Marius(2007) dan* Pratiwi (2015)

c. Pengembangan diri penyuluh (X4) dengan indikator sebagai berikut:

\begin{tabular}{|c|c|c|}
\hline No & Indikator & Parameter \\
\hline 1. & Kemandirian Belajar & $\begin{array}{l}\text { 1. Sumber belajar } \\
\text { 2. Interaksi dengan sumber belajar } \\
\text { 3. Materi belajar }\end{array}$ \\
\hline 2. & $\begin{array}{l}\text { Pengembangan } \\
\text { Penyuluh }\end{array}$ & $\begin{array}{l}\text { 1. kesempatan untuk mengikuti pendidikan formal } \\
\text { kejenjang yang lebih tinggi. } \\
\text { 2. kesempatan untuk mengikuti seminar. } \\
\text { 3. kejelasan tentang promosi karir penyuluh. }\end{array}$ \\
\hline
\end{tabular}

Sumber : Nuryanto (2008)

Selanjutnya definisi variabel faktor dependent dalam penelitian ini sebagai berikut:

d. Kompetensi penyuluh pertanian (Y) yang merupakan variabel dependent dengan indikator (1) kemampuan pemahaman potensi wilayah, (2) kemampuan komunikasi inovasi, (3) kemampuan pengelolaan pembelajaran, (4) kemampuan pengelolaan pembaharuan, (5) kemampuan pengelolaan 
pelatihan, (6) kemampuan pengembangan kewirausahaan, dan (7) kemampuan pemandu sistem jaringan.

Penelitian ini menggunakan analisis regresi yaitu analisis mengenai ketergantungan suatu variabel (variabel terikat) pada satu atau lebih variabel lain (variabel bebas) yang digunakan untuk memprediksi dan atau meramalkan nilai rata-rata hitung (mean) atau rata-rata populasi variabel terikat. Uji regresi linier berganda yaitu pengujian yang digunakan untuk pengaruh antara lebih dari satu variabel bebas terhadap variabel terikat. regresi linier berganda adalah pengaruh secara linear antara dua variabel independen $(\mathrm{X} 1, \mathrm{X} 2, \ldots . \mathrm{Xn})$ dengan variabel dependen $(\mathrm{Y})$

\section{HASIL DAN PEMBAHASAN}

\section{A. Tingkat Faktor-Faktor yang mempengaruhi Kompetensi Penyuluh Pertanian}

\section{a. Karakteristik}

\begin{tabular}{|c|c|c|c|c|}
\hline Karaktersitik Penyuluh & Nilai & Kategori & $\mathrm{n}$ & $\%$ \\
\hline Umur (usia) & $\leq 35$ & Muda & 13 & 23,20 \\
\hline Rata-rata $=39,59$ & $36-46$ & Dewasa & 34 & 60,70 \\
\hline Standar deviasi $=5,99$ & $47-57$ & Tua & 9 & 16,10 \\
\hline Lama Bekerja & $<10$ & Rendah & 24 & 42,90 \\
\hline Rata-rata $=11,82$ & $11-22$ & Sedang & 23 & 41,10 \\
\hline Standar deviasi $=9,80$ & $23-34$ & Tinggi & 9 & 16,10 \\
\hline Tingkat Pendidikan Formal & $<12$ & Rendah(SMA) & - & - \\
\hline Rata-rata $=15,50$ & $13-14$ & Sedang (DIII) & 7 & 12,50 \\
\hline Standar deviasi $=1,34$ & $15-16$ & Tinggi (SI) & 49 & 87,50 \\
\hline
\end{tabular}

Hasil penelitian menunjukan bahwa $60,70 \%$ responden yang kategori dewasa, dengan umur yang sudah dewasaakan lebih mudah menyerappengetahuan baru dan bijak dalam mengambil keputusan, sehingga akanmeningkatkan kemampuannya dalam melaksanakan tugas pokoknya. Semakin cukup umur maka penyuluh akan bersemangat untuk bekerja atau bekerja akan lebih baiksehingga karena penyuluh akan memiliki semangat untuk menambah ilmu dan keterampilan sehingga pekerja dilakukan akan lebih baik selain itu didukung dengan fisik yang lebih kuat, semangat yang lebih besar dan kreatifserta menguasai teknologi informasi. Sejalan dengan pendapat de Cecco (Mardikanto, 1993) menyatakan bertambahnya usia ditandai dengan kematangan fisik dan emosional seiring ditandai dengan kesiapan untuk belajar. Selanjutnya umur yang muda menunjukan bahwa penyuluh pertanian akan kurang memiliki pengetahuan, keterampilan yang cukup dalam pelaksanaan tugas sebagai penyuluh.

\section{b. Motivasi Penyuluh Pertanian}

\begin{tabular}{lllcr}
\hline \multicolumn{1}{c}{ Indikator } & \multicolumn{1}{c}{ Nilai } & \multicolumn{1}{c}{ Kategori } & N & $\%$ \\
& & & & \\
\hline Motivasi Berprestasi & $<36$ & Sangat rendah & 7 & 12,50 \\
Rata-rata 39,89 & $37-38$ & Rendah & 15 & 26,80 \\
Standar deviasi 2,695 & $39-40$ & Sedang & 12 & 21,40 \\
& $41-42$ & Tinggi & 9 & 16,10 \\
& $43-44$ & Sangat tinggi & 13 & 23,20 \\
\hline
\end{tabular}




\begin{tabular}{lllcc}
\hline Motivasi Berafiliasi & $<35$ & Sangat rendah & 2 & 3,60 \\
Rata-rata 39,64 & $36-37$ & Rendah & 7 & 12,50 \\
Standar deviasi 2,467 & $38-39$ & Sedang & 15 & 26,80 \\
& $40-41$ & Tinggi & 18 & 32,10 \\
& $42-43$ & Sangat tinggi & 14 & 25,00 \\
\hline Motivasi akan pekerjaan & $<30$ & Sangat rendah & 2 & 7,10 \\
Rata-rata 38,84 & $35-36$ & Rendah & 7 & 12,50 \\
Standar deviasi 3,318 & $37-39$ & Sedang & 16 & 28,60 \\
& $40-42$ & Tinggi & 25 & 44,80 \\
& $43-45$ & Sangat tinggi & 4 & 7,10 \\
\hline
\end{tabular}

Untuk motivasi berprestasi yang rendah dalam wawancara dengan penyuluh masing penyuluh belum ada yang melanjutkan kejenjang pendidikan yang lebih tinggi, sedangkan untuk mengikuti pelatihan yang dilaksanakan oleh balai pelatihan setiap tahun masih sangat rendah. Kemudian untuk penyuluh sendiri perlu penambahan penambahan insentif, pembinaan serta penghargaan atas sebuah keberhasilan. Motivasi berafiliasi dorongan untuk bersama untuk berhubungan dengan orang lain atas dasar sosial, bekerja dengan orang yang cocok dan berpengalaman dengan perasaan sebagai satu komoditas (Wibowo, 2015). Keinginan bersama dengan petani merupakan pendorong bagi penyuluh berada diwilayah kerjanya dan melakukan kerjasama untuk peningkatan kesejahterahan petani.

c. Lingkungan Kerja Penyuluh

\begin{tabular}{lclcr}
\hline \multicolumn{1}{c}{ Indikator } & Nilai & \multicolumn{1}{c}{ Kategori } & $\mathrm{n}$ & $\%$ \\
\hline Struktur Organisasi & $<26$ & Sangat rendah & 2 & 3,60 \\
Rata-rata 38,27 & $27-31$ & Rendah & 8 & 14,30 \\
Standar deviasi 5,368 & $32-36$ & Sedang & 6 & 10,70 \\
& $37-41$ & Tinggi & 23 & 41,10 \\
& $42-46$ & Sangat tinggi & 17 & 30,40 \\
\hline Sarana dan Prasaran & $<26$ & Sangat rendah & 3 & 5,40 \\
Rata-rata 36,50 & $27-32$ & Rendah & 3 & 5,40 \\
Standar deviasi 5,594 & $33-38$ & Sedang & 31 & 55,40 \\
& $39-44$ & Tinggi & 15 & 25,80 \\
& $45-50$ & Sangat tinggi & 4 & 7,10 \\
\hline Teknologi & $<25$ & Sangat rendah & 1 & 1,80 \\
Rata-rata 35,98 & $26-30$ & Rendah & 4 & 7,10 \\
Standar deviasi 4,061 & $31-35$ & Sedang & 20 & 35,70 \\
& $36-40$ & Tinggi & 24 & 42,90 \\
& $41-45$ & Sangat tinggi & 7 & 12,50 \\
\hline Beban Tugas & $>30$ & Sangat rendah & 5 & 8,90 \\
Rata-rata 36,23 & $31-34$ & Rendah & 10 & 17,90 \\
Standar deviasi 3,766 & $35-38$ & Sedang & 26 & 46,40 \\
& $39-42$ & Tinggi & 14 & 25,00 \\
& $43-46$ & Sangat tinggi & 1 & 1,80 \\
\hline
\end{tabular}

Penyuluh dapat mengembangkan kreatifitas demi kelancaran kegiatan penyuluhan. Dari wawancara yang dilakukan didapatkan informasi bahwa penyuluh di Kabupaten Pasaman melakukan pertemuan setiap bulannya di salah Balai Penyuluhan Kecamatan, kemudian penyuluh diberikan 
tambahan pengetahuan dan keterampilan (training) berdasarkan pendidikan dasar yang dimilikinya. Sebagian penyuluh berpendapat bahwa koordinasi secara vertikal dikelembagaan penyuluhan cukup baik, aspirasi penyuluh dapat disalurkan, hubungan lembaga penyuluh denganlembaga terkait lainya berjalan dengan baik.Kelembagaan penyuluh yang berada pada Dinas Pertanian, sebagian penyuluh menanggapi hal tersebut dengan positif, Jafri. J (2015) menyatakan dalam UU No. 16 Tahun 2006 kelembagaan penyuluh cukup kuat, namun kondisi di lapanganmenunjukkan bahwa wujud struktur organisasibaru belum berhasil dalam mengelola penyuluh dalam peningkatan partisifasi untuk memberdayakankelompok tani.

\section{B. Faktor - faktor yang Mempengaruhi Kompetensi Penyuluh Pertanian}

Kompetensi Penyuluh Pertanian

\begin{tabular}{|c|c|c|c|c|c|c|c|c|}
\hline $\begin{array}{c}\text { Variabel } \\
\text { bebas }\end{array}$ & $\begin{array}{c}\text { Kemamp } \\
\text { uan } \\
\text { pemaha } \\
\text { man } \\
\text { Potensi } \\
\text { Wilayah } \\
\text { (Y11) }\end{array}$ & $\begin{array}{c}\text { Kemamp } \\
\text { uan } \\
\text { Komunik } \\
\text { asi } \\
\text { inovasi } \\
\text { (Y1.2) }\end{array}$ & $\begin{array}{c}\text { Kemamp } \\
\text { uan } \\
\text { Pengelol } \\
\text { aan } \\
\text { pembelaj } \\
\text { aran } \\
\text { (Y1.3) }\end{array}$ & $\begin{array}{l}\text { Kemamp } \\
\text { uan } \\
\text { Pengelol } \\
\text { aan } \\
\text { pembaha } \\
\text { ruan } \\
\text { (Y1.4) }\end{array}$ & $\begin{array}{c}\text { Kemam } \\
\text { puan } \\
\text { Pengel } \\
\text { olaan } \\
\text { pelatiha } \\
\mathrm{n} \\
(\mathrm{Y} 1.5)\end{array}$ & $\begin{array}{c}\text { Kemamp } \\
\text { uan } \\
\text { Pengelol } \\
\text { aan } \\
\text { kewiraus } \\
\text { ahaan } \\
\text { (Y16) }\end{array}$ & $\begin{array}{l}\text { Kemampua } \\
\text { n Pemandu } \\
\text { sistem } \\
\text { jejaringan } \\
\text { (Y1.7 }\end{array}$ & $\begin{array}{c}\text { Total } \\
\text { Dimensi } \\
\text { kompetensi }\end{array}$ \\
\hline & $\mathrm{B}$ & $\mathrm{B}$ & $\mathrm{B}$ & $\mathrm{B}$ & $\mathrm{B}$ & $\mathrm{B}$ & $\mathrm{B}$ & $\mathrm{B}$ \\
\hline Umur & 0,084 & $0,485 * *$ & 0,127 & $-0,098$ & 0,009 & $-0,310 *$ & 0,081 & 0,708 \\
\hline $\begin{array}{l}\text { Lama } \\
\text { bekerja }\end{array}$ & $-0,148$ & $-0,364 * *$ & -0.109 & $-0,070 *$ & 0,191 & 0,222 & 0,047 & 0,007 \\
\hline $\begin{array}{l}\text { Pendidikan } \\
\text { Formal } \\
\end{array}$ & $-0,007$ & 0,090 & $-0,037$ & $-0,018$ & $-0,059$ & 0,105 & $-0,057$ & $-0,038$ \\
\hline $\begin{array}{l}\text { Motivasi } \\
\text { berprestasi }\end{array}$ & $-0,120^{*}$ & $-0,042$ & $-0,122$ & $-0,103$ & $-0,055$ & $-0,071$ & $-0,299 * *$ & $-0,140 * *$ \\
\hline $\begin{array}{l}\text { Motivasi } \\
\text { berafiliasi }\end{array}$ & $-0.213 * *$ & 0,138 & $-0,112$ & 0,060 & 0,068 & 0,069 & 0,213 & $-0,504$ \\
\hline $\begin{array}{l}\text { Motivasi } \\
\text { akan } \\
\text { pekerjaan }\end{array}$ & $0,375 * *$ & 0,124 & $0,317 * *$ & $0,432 * *$ & $-0,022$ & $0,576 * *$ & $-0,105$ & $0,322 * *$ \\
\hline Organisasi & $0,325 * *$ & 0,257 & $-0,232$ & $-0,170$ & 0,265 & 0,018 & $-0,105$ & 0,079 \\
\hline $\begin{array}{l}\text { Sarana } \\
\text { prasaran }\end{array}$ & $-0,073$ & $-0,126$ & 0,070 & 0,184 & $-0,242$ & 0,340 & 0,104 & 0,045 \\
\hline Teknologi & 0,043 & 0,188 & $-0,173$ & 0,004 & 0,332 & $-0,287$ & -0.223 & $-0,020$ \\
\hline $\begin{array}{l}\text { Beban } \\
\text { Kerja } \\
\end{array}$ & 0,142 & 0,089 & $0,655^{* *}$ & $0,370 *$ & $-0,001$ & 0,139 & $0,527 * *$ & $0,326 * *$ \\
\hline $\begin{array}{l}\text { Kemandiri } \\
\text { an Belajar }\end{array}$ & 0,108 & 0,201 & $0,289 * *$ & 0,112 & 0,107 & 0,097 & $0,460 * *$ & $0,220 * *$ \\
\hline $\begin{array}{l}\text { Pengemba } \\
\text { ngan Karir }\end{array}$ & $0,245 * *$ & 0,245 & 0,024 & 0,088 & 0,277 & 0,121 & $-0,039$ & $0,181^{*}$ \\
\hline
\end{tabular}

Keterangan: *nyata pada $\alpha=0,05$ dan ** sangat nyata pada $\alpha=0,01$

Nuryanto (2008) menyebutkan bahwa pengaruh motivasi terhadappeningkatan kompetensi sangat signifikan. Motivasi akan pekerjaan dan berafiliasi memberikan dorongan yangbesar untuk meningkatkan kompetensi pemahaman potensi wilayah. Dorongan penyuluh memotivasi petani untuk meningkatkat kemampuannya untuk peningkatan kesejahteraannyasehingga meningkatkan kemampuan pengelolaan pembaharuan dan kemampuan pengelolaan kewirausahan.

Berdasarkan persamaan tersebut dapat ditunjukkan bahwa untukmeningkatkan kompetensi penyuluh pertanian dapatdilakukan dengan meningkatkan motivasi berprestasi dan motivasi akan pekerjaan, mengurangi beban tugas kemudian didukung oleh kemandirian belajar serta pengembangan karier. Nilai 
R2 sebesar 0,897 yang berarti bahwa besarnya pengaruh karakteristik motivasi lingkungan dan pengembangan karir kompetensi penyuluh sebesar 89,70\% sedangkan sisanya sebesar 10,30\%dipengaruhi oleh faktor lain yang tidak diteliti.

Hasil analisis telah disajikan pada tabel 14 sekaligus telah menjawab pertanyaa penelitian nomor 2 yaitu faktor - faktor yang mempengaruhi kompetensi penyuluh pertanian adalahmotivasi (motivasi berprestasi dan motivasi akan pekerjaan ) lingkungan (beban kerja) dan pengembangan diri penyuluh (kemandirian belajar dan pengemabangan karir penyuluh). Pada pelaksanaan penelitian karakteristik (umur, lama bekerja dan pendidikan) memiliki pengaruh tidak nyata pada kompetensi penyuluh pertanian di Kabupaten Pasaman. Hal ini bearti bahwa karakteristik kurang memberi dukungan terhadap kompetensi penyuluh pada saat ini.

\section{KESIMPULAN}

1. Kompetensi penyuluh pertanian di Kabupaten Pasaman secara umum kategori sedang dilihat dari enam kompetensi penyuluh pertanian berada pada ketegori sedang yaitu : kemampuan komunikasi inovasi, kemampuan pengelolaan pembelajaran, kemampuan pengelolaan pembaharuan, kemampuan pengelolaan pelatihan, kemampuan pengelolaan kewirausahaan dan kemampuan pemandu sistem jejaringan. Sedangkan kemampuan pemahaman potensi wilayah termasuk katergori tinggi.

2. faktor - faktor yang mempengaruhi kompetensi penyuluh pertanian adalah motivasi (motivasi berprestasi dan motivasi akan pekerjaan ) lingkungan (beban kerja) dan pengembangan diri penyuluh (kemandirian belajar dan pengembangan karir penyuluh).

3. Faktor yang kurang berkonstribusi terhadap kompetensi penyuluh pertanian di kabupaten pasaman adalah karakteristik (umur, pendidikan, lama bekerja).

\section{SARAN}

1. Untuk meningkatkan kompetensi penyuluh dengan cara peningkatan kemampuan komunikasi inovasi, kemampuan pengelolaan pembelajaran, pengelolaan pembaharuan, kemampuan pengelolaan pelatihan, kemampuan pengembagan kewirausahaan dan kemampuan pemandu sitem jaringan.

2. Untuk meningkatkan kompetensipenyuluh perlu meningkatkan motivasi dari diri penyuluh dan dukungan lingkungan kerja penyuluh baik dari organisasi, yang menaungi serta pemenuhan sarana parasana dan pengembangan diri penyuluh selain itu penting dilakukan peningkatkan intensitas pelatihan yang didukung oleh lembaga - lembaga pelatihan.

3. Penelitian masih dapat dikembangkan dengan mendalami faktor yang mempengaruhi kompetensi penyuluh terhadap tujuh dimensi kompetensi penyuluh pertanian.

\section{DAFTAR PUSTAKA}

[1] Anwas, Oss.M. 2009. Pemanfaatan Media dalam Pengembangan Kompetensi Penyuluh Pertanian (Kasus di Kabupaten Karawang dan Garut Provinsi Jawa Barat) [Disertasi]. Program Pascasarjana, Institut Pertanian Bogor.

[2] Arifin, B. 2005. Pembangunan Pertanian, Pradigma Kebijakan dan Strategi Revitalisasi Jakarta. Penerbit Gramedia Widiasarana Indonesia. 
[3] Bahua, ML. 2010. Faktor-faktor yang Mempengaruhi Kinerja Penyuluh Pertanian dan Dampak pada Perilaku Petani Jagung di Provinsi Gorontalo. [Disertasi] ITB.Bogor

[4] Boyatzis,RE. 1984. Kumpulan Bahan Kuliah Prinsip-prinsip Penyuluihan, Program Study Ilmu Penyuluhan Pembangunan. Pascasarjana. Bogor. IPB.

[5] BPS Pasaman. 2018. Pasaman Dalam Angka 2018. Pasaman.

[6] BPS Pasaman. 2020. Pasaman Dalam Angka 2020. Pasaman

[7] Djaafar,Z. 2001. Pendidikan Non Formal dan peningkatan Klualitias Sumber Daya Manusia Dalam Pembangunan. Fakultas Ilmu Pendidikan Negeri Padamg.

[8] Hasibuan. 2010. Manjemen Sumberdaya Manusia. Bumi Aksara. Jakarta.

[9] Hubeis, V.S.A., Prino M., Sedyaningsih. S., Ace. S., Arifah. B., Rusli. Y.,dan Mientarti. 2007. Komunikasi Inovasi. Edisi 2. Jakarta Penerbit Universitas Terbuka.

[10] Huda, N. 2010. Pengembangan Kompetensi Penyuluh Pertanian Lulusan Pendidikan Jarak Jauh Universitas Terbuka. [Diseretasi]. Pascasarjana. IPB.

[11] Jelamu,A.M. 2007. Pengembangan Kompetensi Penyuluh Pertanian di Nusa Tenggara Timur [Disertasi]. IPB.

[12] Kartasapoutra. 1991. Teknologi Pertanian. Radar Jaya Offset. Jakarta.

[13] Kartasapoetra, A.G. 1994. Teknologi Penyuluhan Pertanian. Bumi Aksara. Jakarta.

[14] Kementerian Pendayagunaan Aparatur Negara. Peraturan Kementrian Pendayagunaan Aparatur Negara Nomor 2 tahun 2008 tentang Jabatan Fungsional Penyuluh Pertanian dan Angka Kreditnya. Jakarta. 